\title{
2017 Dissertation List
}

PSA is pleased to include here the names of individuals who have completed their doctoral dissertations at political science depart-
ments in the United States during the 2017 calendar year. In order to provide the most accurate information possible, this list is
based on data reported directly from departments.

Ghazal Nadi, American University

Transparent They Endure: Causes and Consequences of Fiscal Transparency in Hybrid Regimes

Sara Salman, American University The Power of Parliaments: Understanding Why and How Parliamentary Power Changes in Transitioning Democracies

William Harder, American University The Administrative Governor and the Parties Environment

\section{Christine Basil, Baylor University} Who Am I to Judge? Rhetoric, Passion, and Rule of Law in Aristotle's Political Thought

David Little, Baylor University Aristotle and Kant on the Noble and the Good

Deborah O’Malley, Baylor University Religious Institutions and Associational Freedom in US Supreme Court Jurisprudence

James Odom, Baylor University Public Debt and the Common Good

Kevin Burns, Baylor University Progressive Constitutionalism: William Howard Taft as Chief Executive and Chief Justice

Alexander Oliver, Boston University Three Essays on the American Public's War Support Calculus: Evidence from Experiments

Douglas Mock, Boston University Natural Law in the US Supreme Court: Tracing the History of Natural Law and Natural Rights Reasoning in Supreme Court Jurisprudence Through the Cases of Calder v. Bull and Corfield v. Coryell

Eniola Soyemi, Boston University Law's Moral Legitimacy and the Significance of Participation
Gregory Winger, Boston University Soft Power by Other Means: Defense Diplomacy as a Tool of International Statecraft

Hae Won Lee, Boston University Assessing the Impact of Transitional Justice: South Korean Experience, 19802016

Jillian Jaeger, Boston University Understanding Minority Incorporation: Evidence from State and Local Politics

Lenka Wieluns, Boston University Understanding the Relationship Between Military Spending Cuts and Military Capacity: European States 2000-2012

Matthew Maguire, Boston University Governance Beyond Governments? The Regulation of Corporate Social Responsibility Through Non-Financial Reporting

Taiyi Sun, Boston University Civil Society Under Authoritarian Rule: Disasters, Social Capital, and their Consequences in Chinese State-Society Relations

Adam Smith, Brandeis University Democratic Medicine: Recongition, Citizenship, and the Politics of Medicalization

Victoria McGroary, Brandeis University Marketing Resistance: Explaining Choices of Violence and Nonviolence Inside Nationalist Movements

Abdulaziz Ahmed Ali Albinali, Claremont Graduate University Oil Policy \& Elites Political Survival: Determinants \& Consequences of Oil Sector Ownership Structure

\section{Andrew D Carico, Claremont Graduate University \\ Rhetorician in Chief: President Obama's Popular Leadership and American Constitutionalism}

\section{Charupol Ruangsuwan, Claremont Graduate University}

The Study of Labor Trafficking in Thailand Fishing Industry: The Case of Migrant Labors from Myanmar in Thailand Fishing Industry

\section{Ichsan Zulkarnaen, Claremont Graduate University}

The Study of Income Inequality in Indonesia: The Case of Globalization and Fiscal Decentralization in Provincial Income Inequality

\section{Jay Michael Hoffpauir, Claremont \\ Graduate University \\ Between the Many and Socrates: A Study of Plato's Crito}

\section{Jean Ock Kang, Claremont Graduate University \\ Finding Clues to Machiavelli's Political Philosophy: Discord, Rationality, and the 'One Man'}

Jessica Leeann England McGuire, Claremont Graduate University Representative Bureaucracy in the States: An Examination of Male and Female Cabinet Secretaries

\section{Jordan Mosiah Bradley, Claremont}

Graduate University The Genius of Republican Liberty: James Madison's Theory of Representation

Loren J Rotner, Claremont Graduate University Popular Leadership Without Populism? A View from the Founding

\section{Mark Russell Becher, Claremont \\ Graduate University}

J.R.R. Tolkien \& the Great War: The Lord of the Rings \& the Modern Civil War

\section{Matthew Daryl Nickens, Claremont} Graduate University

A Dynamic Model of Stabilization and Reconstruction 
Melissa Mahoney Smith, Claremont

Graduate University Civic Dignity, Recognition, and Meaningful Political Participation

\section{Michael Howard Steinman, Claremont \\ Graduate University \\ Legislative Bicameralism: Has It Always Been and Should It Always Be a Foregone Conclusion}

\section{Michael Raphael Davidson, Claremont Graduate University The Role of Irrigation Efficiency in the Implementation of Climate-Smart Agriculture in the Jujuy Province of Argentina}

Nacar Omer Abdelmagid Abdelrahman, Claremont Graduate University Predicting Pro-Government Militia Activity: A Multinomial Logistic Regression Analysis

\section{Rena Salayeva, Claremont Graduate University \\ Finding Democracy in Authoritarian Elections: Strategies For Mobilizing and Rewarding Russian Voters}

\section{Zhidong Fang, Claremont Graduate University Leo Strauss's Understanding of Tyranny: A Reading of the 'Introduction' to On Tyranny}

Jeffrey Cook, Colorado State University Setting the Record Straight: Interest Group Influence on Climate Policy At The Environmental Protection Agency

\section{Megan DeMasters, Colorado State University}

Solving The Rubik's Cube: Understanding the Many Sides of the Municipal Stormwater Program

\section{Megan Ruxton, Colorado State University}

This Budworm's For You: How Framing, Trust, and Participation Affect Attitudes On Natural Resource Management Issues in Atlantic Canada and New England

\section{Amanda Cheney, Cornell University}

Tibet Lost in Translation: Power Politics, Language, and the Mechanics of International Order Transformation
Between the Sinosphere and Westphalia, 1890-1937

\section{Cardona Arroyo Aileen, Cornell \\ University}

Framing Matters: Immigration, the Media, and Public Opinion

Catherine Reyes-Housholder, Cornell

University

Presidentas, Power and Pro-Women Change

Christopher Cairns, Cornell University China's Weibo Experiment: Social Media (Non)Censorship and Autocratic Responsiveness

\section{Comstock Audrey, Cornell University} Domestic Legislatures and International Law: Explaining State Participation and Compliance with United Nations Human Rights Treaties

David Cortez, Cornell University Broken Mirrors: Identity, Duty, and Belonging in the Age of the New La(tinx) Migra

Frederick Setzer, Cornell University Judicial Power in Transitional Regimes: Tunisia and Egypt since the Arab Spring

Gandhi Triveni, Cornell University Layers of Subordination: Intersectional Approaches to Affirmative Action in Rural India

Gregory Thaler, Cornell University Forest Governance and Global Development: The Land Sparing Fallacy in Brazil and Indonesia

Isaac Elfstrom, Cornell University Resistance, Repression, Responsiveness: Workers and the State in China

Isaac Kardon, Cornell University Rising Power, Creeping Jurisdiction: China's Law of the Sea

Katrina Browne, Cornell University The Borders of Conflict: Three Essays on Border Management and Conflict Escalation

Kevin Duong, Cornell University Democratic Terror: Redemptive Violence and the Formation of Nineteenth Century France
Lauren Honig, Cornell University Land, State-Building, and Political Authority in Africa

\section{Mariano Sanchez Talanquer, Cornell}

University

States Divided: History, Conflict, and State Formation in Mexico and Columbia

Natalie Letsa, Cornell University Voting For the Devil You Know: Understanding Electoral Behavior in Authoritarian Regimes

Nicole Weygandt, Cornell University Crude Choice: The Centrality of Learning and Emulation in the Developing World's Transformation of Oil Regimes

\section{Robert Braun II, Cornell University} Religious Minorities and Resistance to Genocide

Rumela Sen, Cornell University Bullets to Ballots: Maoists and the Lure of Democracy in India

Sarah Maxey, Cornell University The Humanitarian Discourse of Force: Explaining US Presidents' Justifications for Military Intervention

Silvana Toska, Cornell University Rebel Passions: How Emotions Fuel the Diffusion of Rebellion

Steffen Blings, Cornell University Political Parties and Social Movements: Mobilizing and Representing Civil Society

Wendy Leutert, Cornell University Economic Reform through Political Leadership in China's State-Owned Economy

Aaron Shapiro, CUNY Graduate Center Dinosaurs for the Digital Age: Party Organization in the Twenty-First Century

\section{Domenico Romero, CUNY Graduate Center}

The Impact of State-Promoted Participation in Democracy and Development: A Comparison of Venezuela and Mexico 
Kristofer Petersen-Overton, CUNY

Graduate Center

Thresholds of Atrocity: Liberal Violence and the Politics of Moral Vision

\section{Matthew Murray, CUNY Graduate \\ Center \\ Stayin' Alive: Transnational Sanctuary and Insurgency}

\section{Puangchon Unchanam, CUNY Graduate Center \\ The Bourgeois Crown: Capitalism and the Monarchy in Thailand, 1946-2016}

\section{Tatianna Carayannis, CUNY Graduate Center \\ Webs of War in the Congo: The Politics of Hybrid Wars, Conflict Networks, and Multilateral Responses, 1996-2003}

\section{Wilnedia Negron, CUNY Graduate Center}

Movements and Political Parties in the 21st Century Exploring the role of ICTs, Human Development, and Political-Activism Culture in East Asia and Latin America

Alexandra Oprea, Duke University Children or Citizens: Civic Education in Liberal Political Thought

Anna Schultz, Duke University The Geography of Accountability

Cindy Cheng, Duke University The Politics of Food Safety

Guadalupe Rojo, Duke University Connecting The Nodes: How Social Capital Enhances Public Services and Infrastructure in Slums

Jiseon Lee, Duke University Guns and Roses: A Study of Violent and Nonviolent Resistance Movements

Joshua Lerner, Duke University Using Ideas As My Maps: Tracing the Flow of Ideas Through the Legislative Process

Matthew Cole, Duke University Dystopia and Political Imagination in the Twentieth Century

Michael Hawley, Duke University Cicero's Legacy and the Story of Modern Liberty
Samuel Bagg, Duke University

The Dispersion of Power: Thinking Democratically in the 21st Century

Ana Paula Von Bochkor Podcameni, Florida International University An Inquiry of the Status of Individual Criminal Responsibility of Children Under International Law Using a Children's Rights Approach

\section{David Tooch, Florida International}

University

The Diffusion of Knowledge in Foreign Policy: The Case of Israel's Technology Transfers as Tools of Diplomacy

\section{Galib Bashirov, Florida International University US Foreign Policy Toward Azerbaijan, 1991-2015}

\section{Graham Slater, Florida International \\ University Foreign Policy Evaluation and the Utility of Intervention}

\section{Jeff Maslanik, Florida International University Immigrant Entrepreneurship and Its Role in Swedish and European Immigration Policy Development}

\section{Karen Clay, Florida International}

University

Rethinking Development Cooperation through South-South Cooperation in Latin America and the Caribbean: Brazil and Haiti

\section{Roberto Flores, Florida International University} Speaking Private Authority: The Construction of Sustainability in Forests and Fisheries

\section{Ryan Opsal, Florida International}

University

Contrasting Oil Security Objectives Within a Grand Streategic Framework: the Case of the United States and China

\section{Thomas Just, Florida International}

University

Contemporary State Policies Toward Antisemitism in Germany and Poland
Tristan DiMontenegro, Florida

International University

China's Interest in Africa: Conflict Or Stabillity?

Yuanyuan Fang, Florida International University

Balance of Power in Regional Institutional Framework: Reassessment of the Us-China-Japan Trilateral Relationship

\section{Alexander Reisenbichler, George}

Washington University

The Politics of Entrenchment: Growth Models and Housing Finance Policy in the United States and Germany

\section{Allison Quatrini, George Washington University "Party" Politics: Ethnic Minority Holiday Celebrations and Ethnic Identity Reinforcement in the People's Republic of China}

\section{Amanda Alcorn, George Washington University Leading the South: Emerging Powers in International Institutions}

\section{Barnett Koven, George Washington University Development Assistance and the Diffusion of Insurgent Violence}

\section{Brian Francisco Reed, George \\ Washington University} Getting His Way: Presidential Preferences and Bureaucratic Relations During Foreign Policy Crises

\section{Diogo De Castilho Penha de Lemos, George Washington University The Politics of Unmixing: Riots, Segregation, and Votes in India}

\section{Jacquelyn Schneider, George Washington University}

The Information Revolution and International Stability: A Multi-Article Exploration of Computing, Cyber, and Incentives for Conflict

\section{Jeannette Haynie, George Washington} University Canaries in the Coal Mines: Does Gender Equality Reduce Domestic Terrorism? 
Jessica Anderson, George Washington

University

Making Locals: Recruitment and the Knowledge Market in International Aid

\section{Kenneth Vincent, George Washington \\ University}

The Strategic Determinants of Oil Stockpiling Behavior

\section{William Cubbison, George Washington}

University

Like the People: Three Essays on Race, Gender, and Political Participation

Diana White, Georgia State University The Impact of Geography and Ethnicity on EU Enlargement: New Evidence from the Accession of Eastern Europe

Gulcan Saglam, Georgia State University Selective Humanity: The Social and Economic Origins of State Responses to Asylum Crises

\section{Hisham Soliman, Georgia State University \\ Defection-Proofed Militaries and Authoritarian Regime}

John Raines, Georgia State University Folding a Losing Brand: Modeling Party Brand Loyalty and the Power of Niche Groups in International Political Economy Decision Making

\section{Mamdouh Shouman, Georgia State}

University

Deserts in the City: White Land and Regime Survival in the Gulf

\section{Yohannes Gedamu, Georgia State}

University

Ethnic Federalism and Authoritarian Survival in Ethiopia

Adriana Alfaro, Harvard University The Belief in Intuition: A Politicophilosophical Reading of Henri Bergson and Max Sheler

\section{Andrei Roman, Harvard University} A Theory of Protest Escalation

Emily Clough, Harvard University Exit, Voice, and Resources: How NGOs Shape State Performance in India
Gabrielle Ramaiah, Harvard University Determinants of Success and Failure in US Advising of Foreign Militaries, 1945present

George Yin, Harvard University Essays on Systemic Theories of Conflict

Jeffrey Javed, Harvard University Land and Retribution: Morality, Mobilization, and Violence in China's Land Reform Campaign, 1950-1952

Jonathan Bruno, Harvard University Democracy Beyond Disclosure: Secrecy, Transparency, and the Logic of SelfGovernment

Jonathan Phillips, Harvard University Good Governance in Poor Places: Explaining Inclusive Politics in Emerging Subnational Democracies

Kara Ross Camanera, Harvard University Aid, Violence, and Intervention: Three Essays on the Transnational Implications of Refugee Policy

Leslie Finger, Harvard University Group Power and Policy Change in Education

Mahhav Khosla, Harvard University Modern Constitutionalism and the Indian Founding

Matthew Kim, Harvard University Public and Elite Opinion on International Human Rights

Melissa Sands, Harvard University How Context Affects Politics: Essays on Causality and Measurement

Michael Hankinson, Harvard University Political Ideology and Development Regulations

Rachel Friedman, Harvard University Probability, Distributive Justice, and the Promise of Social Insurance

Soledad Prillaman, Harvard University Why Women Mobilize: Dissecting and Dismantling India's Gender Gap in Political Participation

Stephen Pettigrew, Harvard University Long Lines and Voter Purges: The Logistics of Running Elections in America
Sungho Kimlee, Harvard University Factions and Orders: from Machiavelli to Madison

Tae-Yeoun Keum, Harvard University Plato and the Mythic Tradition in Political Thought

Volha Charnysh, Harvard University Migration, Diversity, and Economic Development: Post-WWII Displacement in Poland

Zeynep Pamuk, Harvard University Examining the Experts: Science, Values, and Democracy

Adam Brewer, Idaho State University A Bridge's Demise: A Study of Coalitional Narrative Strategies Advanced in the Columbia River Crossing Boondoggle

Katherine Scofield, Indiana University Indigenous Rights and Constitutional Change in Ecuador

Katie Stewart, Indiana University Contentious Conceptions of We the People: An Analysis of Regional Variation in Russian Nation Building Strategies and Outcomes

Kayo Onishi, Indiana University Electoral Gender Quotas and Women's Representation in Developing Countries

Kirk Harris, Indiana University Patronage in Development: Ethnicity and the Politics of Public Goods Provision in Kenya

Laura Bucci, Indiana University Union Decline and Its Consequences For Political Voice: A Look At The American States

Matthew Fowler, Indiana University White Group Consciousness and Dwindling Dominance: The Meaning of Linked Fate Among White Americans in a Changing Demographic Landscape

Ottawa Sanders, Indiana University Existential Threats and the Militarization of Minor Powers: Why Leaders Choose to Pursue and Acquire Nuclear Weapons and Why Some Give Them Up Whereas Others Do Not 
Rafael Khachaturian, Indiana University Discipline, Knowledge, and Critique: Marxist Theory and the Revival of the State in American Political Science, 1968-1989

Yesola Kweon, Indiana University Orienting the Welfare State: Electoral Systems, Social Cleavages, and Policy Priorities

Anne Gillman, Johns Hopkins University Making Culture Moving Margins: Cultural Policy and State-Society Relations in Brazil

\section{Devin Fernandes, Johns Hopkins \\ University}

Constructing the Cause: The Role of Third Party Funders in the Development of Mexican American Interest Group Advocacy

\section{Elizabeth Mendenhall, Johns Hopkins \\ University}

Shifting Grounds: Scientific and Technological Change and International Regimes for the Ocean and Outer Space

\section{Fernando Romero, Johns Hopkins \\ University}

Being in International Relations: The Structure of International Feeling

\section{Joseph Mohorcich, Johns Hopkins University \\ Power Pragmatism}

Kavi Abraham, Johns Hopkins University Governing Through Stakeholders: Systems Thinking and the Making of Participatory Global Governance

\section{Meghan Luhman, Johns Hopkins \\ University \\ From Free Movement to Migration Crisis: Events and Ideas in Europe}

\section{Zachary Reyna, Johns Hopkins \\ University}

The Matter of Law: Reconsidering the Natural Law Tradition

\section{Amanda Clark, Kent State University} Framing Strategies and Social Movement Coalitions: Assessing Tactical Diffusion in the Fight Against Human Trafficking from 2008-2014
Askat Dukenbaev, Kent State University Understanding Elections in "Hybrid Regimes": Why do Citizens Vote in Elections They Do Not Trust? A Case Study of Post-Soviet Kyrgyzstan, 19912016, with Generalizations to the PostSoviet Central Asian States

\section{Elizabeth Moore, Northeastern \\ University}

Transnational Actors and New Venture Creation: Examining Formal and Informal Entrepreneurship From an Interdisciplinary Perspective

James Boesen, Northern Illinois University

A Reconsideration of Montesquieu's Liberal Pacifism

\section{Katherine Paton, Northern Illinois \\ University}

Foundations of Modern Democracy: Machiavelli and the Demise of Greatness

Li-Yin Liu, Northern Illinois University Cultural Influence on Taiwanese Environmental Nongovernmental Organizations' Strategies and on Public Perception of their Strategies

\section{Martin Claar, Northern Illinois University \\ The Swords of Damocles: Explaining Unconventional Weapon Nonuse}

Ronnie Nataatmadja, Northern Illinois University

Decentralization and Public Service in Indonesia: The Influence of the Middle Class

Thomas Rhoden, Northern Illinois University

Neither Refugee Nor Migrant: Comparative-Historical Study of Burmese Migration into Thailand

Timothy Marquez, Northern Illinois University

Race, Ethnicity, Economics, and Federalism: State Sentiment Regarding Noncitizens from 2009-2015

Alison Craig, Ohio State University Policy Collaboration in The United States Congress
Carolyn Morgan, Ohio State University

Fear \& Loathing in the Vaterland: Hate Crimes and Immigrant Political Engagement in Modern Day Germany

Daniel Silverman, Ohio State University Perceptions and Misperceptions in War: Civilian Beliefs about Violence and their Consequences in Pakistan, Iraq, and Beyond

Gabriella Lloyd, Ohio State University Mandating (In) Security? How UN Missions Endanger the Civilians They Intend to Protect

\section{Jakob Miller, Ohio State University} All of the People, All of the Time : An Analysis of Public Reaction to the Use of Deception by Political Elites

Kelly Atkinson, Ohio State University The Effect of Gender-Based Development Policies on Child Recruitment into Conflict

\section{Lauren Ratliff Santoro, Ohio State University} Choosing to Be Changed: How Selection Conditions the Effect of Social Networks on Political Attitudes

Margaret Hanson, Ohio State University Legalized Rent-Seeking : How Dictators Use Civil Courts to Manage Corruption

Megan Bowman, Ohio State University Oil Wealth and Ruling Party Longevity in Democracies

Nicholas Felts, Ohio State University Please Explain Yourself: Mechanisms of Opinion Improvement in Deliverative Forums

Raphael Cunha, Ohio State University Financial Globalization \& Democracy: Foreign Capital, Domestic Capital, and Political Uncertainty in the Emerging World

Sergio Diaz Sierra, Ohio State University The Role of Coherence in the Development of Ideologies: A Case Study of Conservative Thought on Immigration from 1995-2000 
Anne Whitesell, Penn State University Who Represents the "Other"? The Influence of Organized Interests in State Welfare Policy

\section{Christopher Boylan, Penn State \\ University \\ Speaking On Our Behalf : Essays On \\ Political Representation}

\section{Christopher Culver, Penn State \\ University \\ Remittances and Autocratic Regime Durability}

Eleanor Schiff, Penn State University Institutional Political Actors' Relative Influence Across the US Federal Bureaucracy

Emma Leonard, Penn State University Explaining Violence in African Civil Wars: Sierra Leone and Liberia in Comparative Perspective

\section{Joshua Semat, Penn State University} Sympathy and Strength: Understanding Negotiations Between Principals and Agents

Michael Kenwick, Penn State University Securing Control and Controlling Security: Civil-Military Relations and Conflict Processes

Thomas Brawner, Penn State University The Diffusion of Instability in Authoritarian Regimes

\section{Zachary Jones, Penn State University} Interpretable Statistical Learning

Dan Sinh Nguyen Vo, Purdue University Human Rights Treaty Commitment and Compliance: A Machine Learning-based Causal Inference Approach

John Schultz, Purdue University

Revisiting Rustow: An Empirical Assessment of the Relationship Between National Identity and Attitudes Towards Democracy in post-Soviet Russia

Mark Denninghoff, Purdue University

A Hard Pill to Swallow: Federal Intervention and the Peculiarities of Nineteenth Century Mormon Political Pluralism
Summer Forester, Purdue University Security Threats and the Policy Agenda: Understanding State Action on Women's Rights in the Middle East

William Shelby, Purdue University Prone to Drone: Unmanned Aircraft Systems' Effects On Public Support For the Use of Force

Carolina Tchinitian, Rice University Ballots, Vote Casting Procedures, and Electoral Outcomes

James Hedrick, Rice University Immigration Policy in the American States: Attitudes, Adoption, and Outcomes

Mathias Tromborg, Rice University Voter Demands and Representative Behavior

Santiago Alles, Rice University Parties, Incumbents, and the Reform of Electoral Rules in Latin American Democracies

Amanda Roberti, Rutgers University Women Deserve Better: Pro-Woman Issue Framing of Regulatory Abortion Policy in the States

Andrew Spath, Rutgers University Turbulence in Transition? Leader Succession and Government-Activist Interaction in Jordan, Syria, and Beyond

Bo Peng, Rutgers University

Kant's Theory of Duty and Conflict of Rights

Cristina Gherasimov, Rutgers University Postaccession Democratic Backsliding in the New Europe: The Case of Anticorruption Performance

Farah Jan, Rutgers University Adversarial Peace: The Persistence of Nuclear Rivalries

Grace Howard, Rutgers University The Criminalization of Pregnancy: Rights, Discretion, and the Law

Hector Bahamonde, Rutgers University State Capacities in Latin America: Structural Transformations, Elite
Competition, and Fiscal Development (1850-2010)

Ion Marandici, Rutgers University Oligarchic State Capture: Wealthy Elites and State Autonomy in Communist and Postcommunist Countries

John Lesher, Rutgers University Enhancing Minority Electability: Do Majority-Minority Districts Work?"

John Kane, Stony Brook University Party Coalitions and Partisan Behavior in the American Public

Scott Bokemper, Stony Brook University Experiments on Social Safety Nets for Unemployment

Rafael Jacob, Temple University Party, People, or Policy? Uncovering the Impact of Advertising on Voter Behavior in Ballot Initiative and CandidateCentered Campaigns

Travis Blemings, Temple University The Politics of Development Aid: Understanding the Lending Practices of the World Bank Group

Andrew Philips, Texas A\&M University Manipulating the Masses: New Theories of Political Cycles

David Switzer, Texas A\&M University Private Taps, Public Good: Exploring Compliance, Conservation, and Equity in United States Drinking Water

Kendall Funk, Texas A\&M University The Causes and Consequences of Women's Representation in Local Governments

Kristen Carroll, Texas A\&M University When Representatives Work: The Influence of Local Context on Minority Representation

Megan Dyer, Texas A\&M University Rousseau Against Republicanisms; Political Community and Human Order at the Edge of a Tradition

Mitchell Radtke, Texas A\&M University Dictators, Ministerial Cronyism, and International Conflict 
Amira Saleem Jadoon, Rockefeller College of Public Affairs \& Policy, University at Albany, SUNY Aiding Repression? The Effects of US Military Aid on Conflict Intensity and Civilian Targeting

Katherine M Zuber, Rockefeller College of Public Affairs \& Policy, University at Albany, SUNY

Lobbying to Lawsuits: Optimistic Biases and Tactical Transitions in the Movement For LGBT Equality

Rachel Rappaport, Rockefeller College of Public Affairs \& Policy, University at Albany, SUNY

The New Right in Europe: Supply, Demand, and Electoral Performance

Steve S Sin, Rockefeller College of Public Affairs \& Policy, University at Albany, SUNY

While the Enemy is Preoccupied: A Distractionary Theory of Interstate Crisis Initiation

Eunbee Kim, University of Arizona Road to Democratization

Jonathan Beagles, University of Arizona Organizational Values and the Network Governance of International Nongovernmental Organizations

Paul Bezerra, University of Arizona Blunder or Plunder? Donor, Recipient, and Aid Attributes for the Successful Use of Bilateral Aid as a Foreign Policy Tool

Tomas Olivier, University of Arizona Institutional Design and Adaptation in Regional-Scale Common-Pool Resource Institutions: Securing Access to HighQuality Drinking Water in Boston, New York, Portland, and San Francisco

Jenny Kahl, University at Buffalo, SUNY Presidential Leadership, Executive Orders, and Civil Rights in America

Muhammed Erenler, University at Buffalo, SUNY

A Social Control Theory: Bridging the Information-Violence Gap: How Can Information Provision Affect States' Tendency Toward Violence Against Civilians?
Reverien Mfizi, University at Buffalo, SUNY

The Effects of Civil War Outcomes on Economic Disparities, Government Repression and State-Building in Postconflict Countries

Allison Bond, University of California, Berkeley

Wounded Warriors: Contemporary Representations of Soldiers' Suffering

Christian Philips, University of

California, Berkeley

Expansion and Exclusion: Race, Gender, and Immigration in American Politics

Christopher Chambers-Ju, University of California, Berkeley

Democratization and Labor Activation:

Teachers and Parties in Latin America

Denise Van Der Kamp, University of

California, Berkeley

Clean Air at What Cost? The Rise of Blunt

Force Regulation in China

Geoffrey Upton, University of California, Berkeley Negotiating the Sharing Economy: Challenges and Opportunities for Democracy in the Era of Neoliberal Capitalism

Laurel Eckhouse, University of California, Berkeley

Watching the Watchers: Accountability, Democratic Control, and Equal Enforcement of the Law in US Policing

Mark Fisher, University of California, Berkeley

Heroic Democracy: Thucydides, Pericles, and the Tragic Science of Athenian Greatness

Michael Dougal, University of California, Berkeley

Democracy in a Dim Light: Milquetoast Local Newspapers, Candidates that Only Look the Part, and the 2016 Online News Cycle

Nicole Willcoxon, University of California, Berkeley

The Voting Rights Act in North Carolina: Turnout, Registration, Access, and Enforcement
Sheryl Zaks, University of California,

Berkeley

Resilience Beyond Rebellion: How Wartime Organizational Structures Affect Rebel-to-Party Transformation

Raman Deol, University of California, Merced

Traits Versus States: The Interactive Effect of Emotion and Personality on Political Behavior

Aaron Cotkin, University of California, San Diego

Recovery of Virtu: Imitation and Political Practices in the Works of Niccolo Machiavelli

\section{Alan Ward, University of California, San} Diego

Legitimacy's Stutter: The Philosophical Anarchist Challenge and Deliberation's Uncertain Solution

David Searle, University of California, San Diego

Can Television Ads Persuade? Strategy and Choice of Television Advertising in US House of Representatives Elections

Elaine Denny, University of California, San Diego Poverty and the Psychology of Political

John Kuk, University of California, San Diego

An Unequal and Polarized Democracy: Why Has Unequal Growth Caused Party Polarization in the American Public

Kyle Haines, University of California, San Diego

Critical Political Ecology and Environmental Crisis: Rhetoric, Technology, and Decentralization in the US and Mexico

Matthew Nanes, University of California, San Diego

From the Bottom-Up: Policing and Sectarian Conflict in Divided Societies

Mona Roseann Vakilifathi, University of California, San Diego

From the Statehouse to the Schoolhouse: The Effect of State Legislative Institutions on Charter School Growth 
Nazita Lajevardi, University of

California, San Diego

A Comprehensive Study of Muslim American Discrimination by Legislators, the Media, and the Masses

\section{Rumman Chowdhurry, University of California, San Diego \\ Beating Plowshares into Swords: The Impact of the Metropolitan-Military Complex}

Yunkyu Sohn, University of California, San Diego

Measuring Ideology, Dimensionality and Polarization in Politics

Aaron Sparks, University of California, Santa Barbara

Reducing Distance to Increase Action: How Psychological Proximitydrives Political Activism

Francisco Brandao, University of California, Santa Barbara

Campaign Spheres in Latin America: How Institutions Affect Digital Media in Presidential Elections

Hyunsook Moon-Chen, University of California, Santa Barbara

Exchange Rate Policy and Policy Diffusion: Exchange Rate Regime Choices in East Asia

Nicole Filler, University of California, Santa Barbara Gendered Struggles for Social Justice: Asian American Activism and Resistance in the Early 21st Century Los Angeles and Las Vegas

Yanjun Liu, University of California, Santa Barbara

The Making of a Divided Leviathan: Redistribution, Information, and Authoritarian Mass Politics in China

\section{Abdullah Wais Hassan, University of California, Santa Cruz \\ Unreliable Allies: Democrats and the Decline of Public Sector Unions}

Gabriel Filartiga, University of California, Santa Cruz

Adaptive Development: The Micro Genesis of Development as Adaptive Learning
James Beneda, University of California, Santa Cruz Indoctrinated Incoherence: An Institutional Theory of Traumatic Experience

Katherine Blakeley, University of California, Santa Cruz

Fighting Green: How Congress and the Pentagon Make Defense Policy

Logan Puck, University of California, Santa Cruz

Mexico's Private Security Dilemma: Understanding the Relationship Between the Mexican State and the Private Security Industry

\section{Maxim Tabachnik, University of}

California, Santa Cruz

Nation Building in Russia's Buffer Zone: Territorial Citizenship and Separatism in Moldova, Azerbaijan, and Georgia

Samantha Cook, University of California, Santa Cruz

Encountering Metis: Feminist Articulations of UN Security Council Practice

Sandra Harvey, University of California, Santa Cruz

Passing for Free, Passing for Sovereign: Blackness and the Formation of the Nation

Steven Araujo, University of California, Santa Cruz

Bodies of Popular Power: Territorial Activism and Grassroots Control in Argentina

Amanda Blair, University of Chicago Going Beyond Accountability and Untangling the Politics of ConflictRelated Rape

Amanda Maher, University of Chicago The Corrupt Republic: The Contemporary Relevance of Machiavelli's Critique of Inequality and Dependence

Chad Levinson, University of Chicago Moral Subsidy: The Origins of Influential Extra-Governmental Organizations in US National Security Politics
Dina Rashed, University of Chicago Authoritarianism and the Civilianization of Force: Police Power in Militarized Regimes

Emma Stone Mackinnon, University of Chicago

Imperial Promises: The Contested Politics of Human Rights in the Twentieth Century

Gordon Arlen, University of Chicago Oligarchs Among Us: Confronting Wealth and Power in a Democratic Age

Jay Cost, University of Chicago One Great American System: James Madison, Alexander Hamilton, and the Problem of Republican Nationalism

Kathryn Lindquist, University of Chicago

Facing Revolutionary Realities: Understanding High-Intensity State Sponsorship of Nonstate Actors

Marcus Board, University of Chicago Preparing a Defeat: Invisible Power Causing Nonevents By Inhibiting Decision Making and Autonomy

Milena Ann Collan Granillo, University of Chicago

Corrupting Accountability: Elite Control and Corruption Prosecution in Comparative Perspective

Nara Park, University of Chicago The Nature of Japanese Governance: Seikai-Tensin's Political Success in Postwar Japan, 1947-2014

\section{Emmanuel Balogun, University of} Delaware

Regional Convergence in West Africa: Converging Practices and Goverance in the Economic Community of West African States

Faith Okpotor, University of Delaware Electing Violence: Explaining PostElection Violence in Africa

Samantha Kelley, University of Delaware

Welcome "Guests"? Migrant Labor rights in the US Guest Worker Program 
Victoria Sanchez, University of Delaware Radioactive Reversal? The Fukushima Accident as a Focusing Event for Comparative Policy Change on Nuclear Energy

Alison Mintz, University of Georgia Geostrategy and Identity: Motivations for the Russian Sphere of Influence

Allison Turney, University of Georgia Major Powers, Minor Powers, and the Institutional Design of Asymmetric Alliance Treaties

Carolin Pursar, University of Georgia The Concept, Measurement, and Determinants of Human Security: A Spotlight on Personal Security

Chase Meyer, University of Georgia The Messenger Matters: Race, Party, and the Perceptions of Candidates by White and Nonwhite Voters

Jason Villarreal, University of Georgia Booker T. Washington and Preparatory Citizenship

Jennifer Inglett, University of Georgia The Utility of Foreign Policy Goals: How Goals Affect Threat Perceptions

John Willingham, University of Georgia Enter Stage Right: Rebel Leader Type \& Conflict Dynamics in Intrastate War

Joshua Massey, University of Georgia Grand Strategy in the Information Age: An Examination of Global Cyber Technology and the Rise of Public Capacity

Rongrong Liu, University of Georgia The Role of Multinational Corporations in Chemical Nonproliferation

Ryan Williamson, University of Georgia Examining the Effects of Institutional Design on Electoral Outcomes

Steven Kaszycki, University of Georgia The Unbroken Circle: Political and Tax Aggressiveness, with Application to the Pharmaceutical Industry

Steven Walter, University of Georgia Rethinking Repression
Margarita Ramirez Rubio, University of

Houston

Why do Legislators COF? Congressional Open Forum Speeches and Electoral Incentives in Presidential America

Markie McBrayer, University of Houston The Institutional Foundations of Local Decisionmaking \& Representation

Yeaji Kim, University of Houston Education and Democracy

Audrey Neville, University of Illinois, Urbana-Champaign The Political Psychology of Perceptions of Latino Voters and of Latino Politicians

Benjamin Kantack, University of Illinois, Urbana-Champaign Mind the Gap: Issue Positions, Candidate Preferences, and Motivated Reasoning in US Presidential Elections

Blair Niece, University of Illinois, Urbana-Champaign

Partial Diffusion and Backsliding in International Standards

David Bowden, University of Illinois, Urbana-Champaign

Politics Among Rebels: The Causes of Division Between Dissidents

Duu Renn, University of Illinois, UrbanaChampaign

What's the Point of Postwar Elections? Power, Institutions, and Politics in the Wake of Civil War

Matthew Cawvey, University of Illinois, Urbana-Champaign

Personality and the Political System: An Exploration of the Psychological Roots of Political Support

Matthew Martin, University of Illinois, Urbana-Champaign

Into the Fold: Security Fears and Power Sharing the Credible Commitment of Rebel Military Integration and Durable Peace

Tarah Williams, University of Illinois, Urbana-Champaign

The Fragility of Tolerance: Rights, Responsibilities, and the Challenge of Speaking Up
Abigail Matthews, University of Iowa The Diffusion of Precedent Across State Supreme Courts

Elizabeth Maltby, University of Iowa The Political Origins of Racial and Ethnic Inequality

Kellen Gracey, University of Iowa The Macro Polity and Public Opinion in Religious Context

Kyu Young Lee, University of Iowa Political Clout of Government Bondholders: How Government Bondholders Expect and Affect States' Conflictual Behaviors

Michael Ritter, University of Iowa Accessible Electoral Systems: State Reform Laws, Election Administration, and Voter Turnout

Ray Ou Yang, University of Iowa The Way to a Dominant International Currency: A Political General Theory and the Prospect of the Renminbi's Rise

Shuai Jin, University of Iowa

Politics of Economic Inequality in China: Government Propaganda and Public Opinion

Adam Brown, University of Kansas Of Six Minds on the Matter:A Psychologybased Typology of Hawkish and Dovish Decision Makers

\section{Ben Rogers, University of Kansas} The Best Subset in Validation Algorithm: Testing Political Scientific Theory Via Predictive Analytics

Brittnee Carter, University of Kansas Analyzing the Criminal Justice and Military Models of Counterterrorism: Evidence from the United States

Chris Higginbotham, University of Kansas

Procuring the Cross of Iron: The Effect of Congressional Approval on the Defense Budget

Ginger Feather, University of Kansas Moroccan Feminists: The Innovators and Drivers Behind Progressive Legal Reform Successes, Setbacks, and Future Priorities 
Lidiya Zubytska, University of Kansas Explaining Foreign Policy Change in Transitional States: A Case Study of Ukraine between Two Revolutions

Ranya Ahmed, University of Kansas Religion and Ideology as Determinants of Contentious Politics: Terrorism and Beyond

\section{Annamarie Rannou, University of}

Kentucky

Ethnic Xenophobia as Symbolic Politics: A Cross-National Study of Anti-Migrant Activism from Brussels to Beirut

Austin Trantham, University of Kentucky

The State House and the White House: Gubernatorial Rhetoric During the Obama Administration

Gabriela Rangel, University of Kentucky Voting as a (Mandatory) Duty: Citizen Attitudes, Political Engagement, and Party Outreach Under Compulsory Voting

John Poe, University of Kentucky How the Climate of Opinion in States and Countries Influences Gay Rights

Alyssa Grahame, University of

Massachusetts, Amherst

Democracy in Crisis: Social Mobilization Against Financial Capital

Ivelisse Cuevas-Molina, University of Massachusetts, Amherst

VoterTurnout Overreports: Measurement, Modeling, and Deception

Khorapin Phuaphansawat, University of Massachusetts, Amherst

My Eyes are Open but My Lips are Whispering: Linguistic and Symbolic Forms of Resistance in Thailand during 2006-2016

Moise St. Louis, University of

Massachusetts, Amherst

Looking Beyond the Rubble Toward Louverturean Statecraft: The PostOccupation State and the Historical Fault Line of Responsive Government in Haiti (1791-2010)

Christopher Skovron, University of Michigan

Perceptions of Public Opinion and Representation in American Politics
Geoffrey Lorenz, University of Michigan Prioritized Interests: Why Congressional Committees Address Some Problems and Ignore Others

\section{Greenwald Diana, University of \\ Michigan}

Pathways to Self-Rule: Occupation, Resistance, and State-Building in Palestine and Timor-Leste

\section{Huzefa Hakim Khalil, University of Michigan \\ Europe: Requiem for an Idea?}

Jennifer Chudy, University of Michigan Racial Sympathy in American Politics

Jonathan Fuentes, University of Michigan

Exploring the Dynamics of Representation, Institutional Rules, and Policy Outcomes in the US States

Juan E. Marcano, University of Michigan

Politics as Hope: Towards the Elpidology of the Oppressed from Paulo Freire's Political Realism

Kirill Kalinin, University of Michigan The Essays on Election Fraud in Authoritarian Regimes

Maiko Heller, University of Michigan The Empirical Implications of Interparty Bargaining in Multiparty Governments

Marie Puccio, University of Michigan Effects of Education on Political Perspectives in Haiti

Meredith Blank, University of Michigan The State's Use of Force

Neveser Koker, University of Michigan Gendering East and West: Transnational Politics of Belonging in the Ottoman Empire and France, 1718-1905

Vanessa Cruz Nichols, University of Michigan

Latinos Rising to the Challenge: Political Responses to Threat and Opportunity Messages

Vincent Fusaro, University of Michigan The Spirit of '96: States \& the Implementation of Temporary Assistance for Needy Families
Adam Olson, University of Minnesota Confict, Consensus, and Opportunity: Congress and the Development of the American Welfare State

Bryan Nakayama, University of Minnesota

From Aerospace to Cyberspace: The Evolution of Domains of Warfare

Chase Hobbs-Morgan, University of Minnesota

Greenhouse Democracy: A Political Theory for Climate Change

Christina Farhart, University of

Minnesota

Look Who is Disaffected Now: Political Causes and Consequences of Learned Helplessness in the US

Emily Baer-Bositis, University of Minnesota

Organizing for Reform: the Democratic Study Group and the Role of Party Factions in Driving Institutional Change in the House of Representatives

Lucas Lockhart, University of Minnesota Guardians of Market Integrity: Political Institutions, Regulatory Independence, and Stock Market Development

Ore Koren, University of Minnesota Hunger Games: Analyzing Relationships Between Food Insecurity and Violence

Paul Snell, University of Minnesota Power and the Quest for Justice

Sergio Valverde, University of Minnesota A Speculative Theory of Politics: Logic of the Pary-Form

Clinton Swift, University of Missouri Agendas and Committees in American State Legislatures: Causes and Consequences of Matching Priorities with Institutional Roles

Colton Heffington, University of Missouri

Foreign Policy During Intrastate Conflict: Patterns of Support, Retaliation, and Opportunism

Jeffrey King, University of Missouri Shared Affinities: The Effect of Shared Neoliberal Orientation on Foreign Policy Behaviors 
Jessica Anderson, University of Missouri Justice for All? Explaining the International Criminal Court's Situation Selection

\section{Kenneth Bryant, Jr., University of} Missouri

Systematic Stages of Group Realignment Case Study: Black Group Realignment 1912-1964

Krisztina Pusok, University of Missouri Determinants and Consequences of Private Environmental Regimes

Thomas Guarrieri, University of Missouri The Counterterrorism Escalation Game: How Leadership Targeting Affects the Behavior of Terrorist Groups

Brendan Morris, University of Nevada, Las Vegas

Obligations of the State: State Behavior and the Occurrence of State Success

Katherine Eugenis, University of Nevada, Las Vegas

Effects of Judicial Primary Election Systems On Challenger Emergence and Candidate Success

Kenneth Retzl, University of Nevada, Las Vegas

Audits and Accountability in Nongovernmental Organizations

Nathan Henceroth, University of Nevada, Las Vegas

The Engaged Eurosceptic: Explaining Eurosceptic Success and Failures in European Parliamentary Elections

Benjamin Gross, University of North Texas Knowing What is Useful: Rousseau's Education Concerning Being, Science, and Happiness

\section{Brandon Stewart, University of North Texas \\ Crossing Over: Essays on Ethnic Parties, Electoral Politics and Social Conflict}

Christopher Macaulay, University of North Texas

Territorial Issue Salience: Escalation, Resources, and Ethnicity
Jinrui Xi, University of North Texas

The "King" Arrives: Chinese Government Inspections and their Effects

Wei Feng Tzeng, University of North Texas

Elections and Authoritarian Rule: Causes and Consequences of Adoption of Grassroots Elections in China

Yen-Hsin Chen, University of North

Texas

Protests in China: Why and Which Chinese People Go to the Street

Gulce Tarhan Celebi, University of Oregon

The Constitutional Court of Turkey from State-in-Society Perspective

Thibaud Henin, University of Oregon Standards as Strategies: Using Transnational Private Standards as Lobby Governments

Ashley A. Tallevi, University of

Pennsylvania

Making the Political Personal: Health Insurance, State Visibility, and Civic Perceptions

\section{Elspeth M. Wilson, University of}

Pennsylvania

The Reproduction of Citizenship: How the US Government Shaped Citizenship During the 2oth Century by Regulating Fertility, Procreation, and Birth Across Generations

\section{Matthew M. Kavanagh, University of} Pennsylvania Constitutionalizing Health: Rights, Democracy, and the Political Economy of Health Policy

\section{Robinson Woodward-Burns, University} of Pennsylvania American Reconstitution: How the States Stabilize American Constitutional Development

Sidney A. Rothstein, University of Pennsylvania Worker Mobilization in Twenty-First Century Liberalism
Alexis Mootoo, University of South

Florida

Structural Racism: Racists Without Racism in Liberal Institutions within Colorblind States

Nicole Ford, University of South Florida Measuring Trust in Post-Communist States: Making the Case for Particularized Trust

\section{T. Adam Golob, University of South} Florida

Hidden: A Case Study on Human Trafficking in Costa Rica

Clay Fuller, University of South Carolina The Economic Foundations of Authoritarian Rule

Paul Strickler, University of South Carolina

Partisan Polarization, Social Identity, and Deliberative Democracy in the United States

Christopher Acuff, University of Tennessee Beyond the City-County Divide: Race, Referenda, and Representation in Consolidated Governments

Michael Moltz, University of Tennessee Preferences for Employment in the Government Workforce

Royal Cravens, University of Tennessee Politics at the Intersection of Sexuality

Treston Wheat, University of Tennessee America's Imperfect War: The Ethics, Law, and Strategy of Drone Warfare

Curt Childress, Univeristy of Texas, Dallas

Lochner and the Police Powers Doctrine

Imrana Iqbal, Univeristy of Texas, Dallas International Law of Nuclear Nonproliferation: Legal and Theoretical Analysis of its Applicability to Nonnuclear Weapons States and Nonstate Actors

Razan Albana, Univeristy of Texas, Dallas Juditialization of Repression: Exceptional Courts and Human Rights 
Jennifer Seelig, University of Utah Is a Woman's Place in the Community Council? Salt Lake City's Neighborhood Governance Institutions and the Empowerment of Women

Jennifer Yim, University of Utah Delinquency's Treatment: Why Interactions Produce Policy and Identity in Secure Juvenile Facilities

Marin Bryce, University of Utah The Politics of Genetically Modified Food Aid: Zambia and Malawi in 2002

Samuel Field, University of Utah Globalization and Political Parties: Is there a Connection?

Tal Buenos, University of Utah The Power of "Genocide": International Law as a Dialectical Profession of Hard Power through Soft Power Toward Legal Power

Andrew Clarke, University of Virginia Essays on American Party Factions

Boris Heersink, University of Virginia National Party Organizations and Party Brands in American Politics

Harrison Frye, University of Virginia The Sociality of Freedom

Matt Scroggs, University of Virginia Democracies Under Fire: How Democratic Targets and Allies Respond to Coercive Threats

Nicole Pankiewicz, University of Virginia The Good American: An Exploration of American Understandings of Citizenship

Thomas Gray, University of Virginia Retention Politics in State Supreme Courts: The Power of Elites and the Limitations of Voter Oversight of the Judicial Branch

Carolina Johnson, University of

Washington, Seattle

Engaging Democracy: An Institutional Theory of Participatory Budgeting

Caterina Rost, University of Washington, Seattle

The Divergent Trajectories of an Idea: Sustainable Development in Germany and the United States
Emily Gade, University of Washington,

Seattle

Connection and Resistance: Civilian Experiences of Violence in Conflict Zones and their Impact on Civilians' Preference for Violent and Nonviolent Resistance

Erin Adam, University of Washington, Seattle

Queer Alliances: Paradoxes and Power in the Formation of Rights-Based Movement Coalitions

Jennifer Noveck, University of

Washington, Seattle

Autocratic Brews: Small Firm Politics in China's Emerging Craft Beer Industry

John Buchanan, University of

Washington, Seattle

The Rise of the Bo: Autonomous Strongmen, Opium Capital, and State Formation in Mainland Southeast Asia (1948-1996)

Kahraman Filiz, University of

Washington, Seattle

Claiming Labor Rights as Human Rights: Legal Mobilization at the European Court of Human Rights

Xiao Ma, University of Washington, Seattle

Guardians and Gridlocks: Bureaucracy, Bargaining, and Authoritarian Policymaking

Yu Sasaki, University of Washington, Seattle

Precocious Enough to Rationalize Culture? Explaining the Success and Failure of Nation Building in Europe, 1400-2000

\section{Brianne Wolf, University of Wisconsin,} Madison

Tasting Liberty: Affective Judgement in the Work of Rousseau, Smith, and Tocqueville

Katelyn Jones, University of Wisconsin, Madison

The Weight of Words: Deliberation and Policymaking in the United Nations Security Council
Mark Toukan, University of Wisconsin, Madison

International Politics by Other Means: Interstate Rivalries and the Escalation of Civil Conflicts

Matthew Scharf, University of

Wisconsin, Madison

Development or Decay? Investment Outcomes Following Political Turnover in Madagascar

Nicholas Barnes, University of

Wisconsin, Madison

Monopolies of Violence: Gang Governance in Rio de Janeiro

Ryan Power, University of Wisconsin, Madison

Macroprotectionism: The Causes and Consequences of Temporal Variation in Mass Trade Preferences

Samantha Vortherms, University of Wisconsin, Madison

A Comparative Political Economy of China's Local Citizenship

Sarah Bouchat, University of Wisconsin, Madison

Common Knowledge: Elicited Priors in Political Science

Thomas Bunting, University of Wisconsin, Madison

Democracy at the Ballpark: Sport, Spectatorship, and Politics

Cagla Mavruk Cavlak, Wayne State

University

Regional Power Politics: The Behavior and Motivations of Regional Powers in Settings of Conflict and Coalition

Catherine Schmitt-Sands, Wayne State University

The Political Determinants of Food Security: Democracy, Decentralization and Federalism

Malek Abduljaber, Wayne State

University

Political Ideology in the Arab World

Robert Mahu, Wayne State University Rationalization and the Individuals with Disabilities in Education Act: Exploring the Characteristics of Multilevel Performance Monitoring and Improvement 


\section{Amber Brugnoli, West Virginia}

University

Postconflict Occupations: A New Analysis Using Comparisons of Contextual, Hybrid, and Instigated Factors in Germany, Japan, and Iraq

\section{Franchesca Nestor, West Virginia}

University

Narrow Representation? The Impact of Implicity and Explicitly Racial Issues on Opinion and Representation

\section{Gillian Beach, West Virginia University}

Diffusion or Dissent: Examining International Family Planning Frames and Domestic Policy Divergence
Jeri Kirby, West Virginia University Rehabilitation in the Punitive State: An Oxymoron? An Examination of Rehabilitation and Punitive Practices in the United States

Lauren Santoro, West Virginia University Representation and Policymaking: Women Participating in the US House

\section{Matthew Arp, West Virginia University} Civil Religion and Ontological Threat

\section{Michael Edward Thunberg, West}

Virginia University

Presidential Executive Orders: The Bureaucracy, Congress, and the Courts
Abida Bano, Western Michigan

University

Women's Representation in Local Democracy: Formal and Informal Institutions in Khyber Pakhtunkhwa, Pakistan

\section{George Lluberes, Western Michigan University}

Controlling Political Corruption in Latin America: Institutional Constraints on Executive Power

\section{Sarah Perez, Western Michigan University}

A House Divided Cannot Stand: The Case for Latino-Black Coalitions 